\title{
FAKTOR-FAKTOR YANG BERISIKO DENGAN KEJADIAN DEMAM BERDARAH DENGUE DI KECAMATAN PURWOKERTO TIMUR KABUPATEN BANYUMAS TAHUN 2016
}

\author{
Taraegi Evani Kanigia ${ }^{1)}$, Tri Cahyono ${ }^{2)}$, Asep Tata Gunawan ${ }^{3)}$ \\ Jurusan Kesehatan Lingkungan, Politeknik Kesehatan Kemenkes Semarang, \\ Jl. Raya Baturaden KM 12 Purwokerto, Indonesia
}

\begin{abstract}
Abstrak
Demam berdarah dengue Penyakit demam berdarah dengue adalah penyakit menular yang disebabkan oleh virus dengue dan ditularkan melalui gigitan nyamuk Aedes aegypti. Jumlah kasus DBD di Kecamatan Purwokerto Timur periode Januari-Maret tahun 2016 sebanyak 60 kasus. Tujuan dari penelitian ini adalah Mengetahui faktor risiko lingkungan, perilaku, dan kepadatan hunian dengan kejadian Demam Berdarah Dengue (DBD) di Purwokerto Timur Tahun 2016. Metode penelitian yang digunakan analitik observasional dengan desain Studi Case Control, jumlah sampel 40 kasus dan 40 kontrol. Variabel yang diteiti meliputi kebiasaan menggunakan reppelent, adanya ruang gelap, kebiasaan menggantung pakaian, adanya tempat penampungan alami, dan kepadatan hunian. Data dianalisis ke dalam univariat, bivariat dengan analisis Chi-square dan multivariat dengan uji regresi logistik.Hasil analisis bivariat kebiasaan menggunakan repplent $(p=0,128$ OR=2,510), adanya ruang gelap $(p=1,000$ OR $=1,129)$, kebiasaan menggantung pakaian $(p=0,277$ OR=2,122), adanya tempat penampungan alami $(p=0,213$ OR=2,125), kepadatan hunian $(p=0,605$ OR=1,495). Hasil bivariat menunjukan seluruh variabel yang diteliti tidak ada hubungan dengan kejadian DBD karena nilai $p$ lebih besar dari nilai $\square=0,05$. Hasil multivariat faktor yang paling signifikan kebiasaan menggunakan reppelent $(p=0,079 O R=2,510)$.Simpulan penelitian ini adalah tidak ada variabel yang berhubungan dengan kejadian DBD. Disarankan untuk masyarakat untuk mewaspadai faktor-faktor DBD lainnya.
\end{abstract}

Kata kunci : Lingkungan fisik rumah, perilaku, dan kepadatan hunian

\begin{abstract}
Risk Factors Of Dengue Fever Case In Subdistrict East Purwokerto Of Banyumas Year 2016 Dengue fever disease is a contagion caused by dengue virus and transmitted by bite of Aedes aegypti mosquitos. The amount of DBD cases in Subdistrict East Purwokerto from January-March in 2016 were 60 cases. The purpose of this research is to find out environmental risk, behavior, and population density with Dengue Hemografic Fever (DHF) cases in East Purwokerto in 2016.The method used in this research is observational analytic with Case Control study design, the amount of sample was 40 cases and 40 controls. Variable examined in this research were the habit of using repellent, the existence of dark room, the habit of hanging clothes, the existence of natural saving water, and population density. The data was analyzed into univariate, bivariate used Chi-square and multivariate used logistic regression test. The result of bivariate analysis used repellent $(p=0,128$ OR=2,510), the existence of dark room ( $p=1,000$ OR=1,129), the habit of hanging clothes $(p=0,277$ OR=2,122), the existence of natural saving water $(p=0,213$ OR=2,125), population density $(p=0,605$ OR=1,495). Based on the result of bivariat shown that there were no variabel correlated with DHF case becuase the $p$ value more than $\square=0,05$. The multivariate factor result which is most significant was the habit of using repellent $(p=0,079 \mathrm{OR}=2,510)$. The conclusion of this research is that there was no variable correlated with DBD case. The researcher suggest to people to wary about other DBD factors.
\end{abstract}

Keywords : Houses' physical environment, behavior, and population density

\section{PENDAHULUAN}

Subtainable Development Goals (SDGs) yang telah disepakati oleh anggota negara-negara PBB menjelaskan pada tujuan ketiga bahwa yaitu memastikan hidup sehat dan memajukan kesejahteraan bagi semua orang disemua umur. (PBB Indonesia, 2015).

DBD adalah penyakit menular yang disebabkan oleh virus dengue dan ditularkan oleh nyamuk Aedes

1) Email : taraegiek@gmail.com

2) Email : statistikan@yahoo.com

3) Email : aseptatagunawan@yahoo.co.id aegypti dan Ae. albopictus, ditandai dengan demam 2 - 7 hari disertai dengan manifestasi perdarahan, penurunan jumlah trombosit $<100.000 / \mathrm{mm} 3$, adanya kebocoran plasma ditandai peningkatan hematokrit $\geq 20 \%$ dari nilai normal. (Ditjen P2PL, 2013).

Sebagaimana model epidemologi penyebaran penyakit infeksi yang dibuat oleh John Gordon, penularan penyakit DBD juga dipengaruhi oleh

Keslingmas Vol. 35 Hal. 278-396 Desember 2016 | 293 
interaksi 3 faktor yaitu 1) faktor penjamu dalam hal ini adalah manusia yang rentan terkena atau tertular penyakit DBD. 2) faktor penyebar (vektor) dan penyebab penyakit (agent) dalam hal ini adalah vrius DEN tipe 1-4 sedangkan Aedes aegypti sebagai penyebar penyakit DBD. 3) faktor lingkungan yakni lingkungan yang memudahkan terjadinya kontak penular penyakit DBD (Ginanjar, 2007). Menurut profil kesehatan Indonesia tahun 2013 bahwa DBD dapat muncul sepanjang tahun dan dapat menyerang seluruh kelompok umur, penyakit ini berkaitan dengan kondisi lingkungan dan perilaku masyarakat.

Penelitian sebelumnya, yang dilakukan oleh Dardjito dkk pada peneltian beberapa faktor risiko yang berpengaruh pada kejadian penyakit DBD di Kabupaten Banyumas tahun 2008, bahwa beberapa faktor yang kontribusi atau mendukung terjadinya DBD, yaitu kebiasaan menggantung pakaian dan kebiasaan menggunakan obat anti nyamuk (repellent) selain itu adanya ruang gelap serta Tempat Penampungan Air juga merupakan salah satu faktor resiko terjadinya DBD. Menurut penelitian Nugroho (1999) fakttor yang dapat mempengarhu DBD adalah kepadatan hunian yang dikarenakan nyamuk sangat aktif mencari makan dalam waktu yang pendek.

Jumlah kasus Demam Berdarah Dengue (DBD) di Kabupaten Banyumas pada 5 (lima) tahun terakhir terjadi peningkatan dan penurunan. Hasil pendataan dari Dinas Kesehatan Kabupaten Banyumas jumlah kasus DBD adalah sebagai berikut : 696 orang (tahun 2010), 201 orang (tahun 2011), 200 orang (tahun 2012), 543 orang (tahun 2013), 209 orang (tahun 2014), dan pada tahun 2015 hingga bulan September telah terjadi sebanyak 221 kasus DBD. Kasus kematian DBD pada tahun 2016 dibulan JanuariMaret sebanyak 13 kematian yang tersebar di kabupaten Banyumas salah satunya di Purwokerto Timur yaitu Kelurahan Sokanegara.

Kasus DBD pada tahun 2016 periode bulan Januari hingga Maret sudah mencapai 60 kasus, hingga tanggal 30 Maret 2016 sudah terdapat 1 kasus kematian Demam Berdarah Dengue di Sokanegara, Purwokerto Timur pada tahun 2016.

Tujuan penelitian adalah Mengetahui faktor risiko lingkungan (ruang gelap dan adanya tempat penampungan alami), perilaku (kebiasaan menggunakan repellent dan menggantung pakaian), dan kepadatan hunian dengan kejadian Demam Berdarah Dengue (DBD) di Purwokerto Timur Kabupaten Banyumas Tahun 2016.

\section{BAHAN DAN METODE}

Metode penelitian ini adalah penelitian analitik observasional dengan desain studi Case Control, jumlah sampel kasus sejumlah 33 kasus dan 33 kontrol, total adalah 66 sampel. Variabel yang diteliti meliputi kebiasaan menggunakan repellent, adanya ruang gelap, kebiasaan menggantung pakaian, adanya tempat pena,pungan alami, dan kepadatan hunian.

\section{III.HASIL DAN PEMBAHASAN}

a. Gambaran Umum Wilayah Purwokerto Timur Wilayah Kecamatan Purwokerto Timur berada di Kabupaten Banyumas Provinsi Jawa Tengah. Luas wilayah Kecamatan Purwokerto Timur 841,93 Ha, tinggi Ibu Kota Kecamatan dari permukaan laut $74 \mathrm{M}$. Kecamatan Purwokerto Timur terdiri dari 6 Kelurahan yaitu Kelurahan Sokanegara, kelurahan Kranji, Kelurahan Purwokerto Lor, Kelurahan Purwokerto Wetan, Kelurahan Mersi, dan Kelurahan Arcawinangun.

b. Keadaan Lingkungan

Jumlah rumah keseluruhan pada tahun 2014 adalah 6.880 rumah, yang telah diperiksa dan memiliki jamban sehat sebanyak 1.217 atau $66,23 \%$. Rumah yang memiliki tempat sampah sebanyak 1,843 dan rumah yang memiliki tempat sampah sehat sebanyak 1.188 atau 64,8\%. Rumah yang memiliki pengelolaan air limbah sebanyak 1.800 rumah,hanya 1435 rumah pengelolaan air limbahnya yang memenuhi syarat.

c. Derajat Kesehatan

Morbiditas DBD pada tahun 2014 didapatkan kasus Demam Berdarah Dengue sebanyak 31 kasus per 100.000 penduduk. Pada tahun 2015 kasus Demam Berdarah menjadi 125 kasus. Pada tahun 2016 periode januari hingga maret sudah terjadi 60 kasus DBD hingga ditetapkan berstatus KLB. 
Hasil Analisis Univariat

\begin{tabular}{|c|c|c|c|c|c|}
\hline \multirow{3}{*}{ no } & \multirow{3}{*}{\multicolumn{2}{|c|}{ variabel }} & \multicolumn{2}{|c|}{ kelompok } & \multirow{3}{*}{ Total } \\
\hline & & & \multirow{2}{*}{$\begin{array}{l}\text { Kasus } \\
\text { Jumlah }\end{array}$} & \multirow{2}{*}{$\begin{array}{l}\text { Kontrol } \\
\text { Jumlah } \\
\end{array}$} & \\
\hline & & & & & \\
\hline \multirow{3}{*}{1} & \multirow{3}{*}{ Kebiasaan menggunakan reppelent } & Tidak & $\begin{array}{r}16 \\
48,5 \%\end{array}$ & $\begin{array}{r}9 \\
72,7\end{array}$ & $\begin{array}{r}25 \\
37,9 \%\end{array}$ \\
\hline & & Ya & $\begin{array}{r}17 \\
51.5 \%\end{array}$ & $\begin{array}{r}24 \\
27,3\end{array}$ & $\begin{array}{r}41 \\
62,1 \%\end{array}$ \\
\hline & & Jumlah & $\begin{array}{r}33 \\
100,0 \% \\
\end{array}$ & $\begin{array}{r}33 \\
100,0 \% \\
\end{array}$ & $\begin{array}{r}66 \\
100 \%\end{array}$ \\
\hline \multirow{3}{*}{2} & \multirow{3}{*}{ Adanya Ruang Gelap } & $\mathrm{Ya}$ & $\begin{array}{r}16 \\
48.5 \%\end{array}$ & $\begin{array}{r}17 \\
51.5 \%\end{array}$ & $\begin{array}{r}33 \\
50,0 \%\end{array}$ \\
\hline & & Tidak & $\begin{array}{r}17 \\
51.5 \% \\
\end{array}$ & $\begin{array}{r}16 \\
48.5 \% \\
\end{array}$ & $\begin{array}{r}33 \\
50,0 \% \\
\end{array}$ \\
\hline & & Jumlah & $\begin{array}{r}33 \\
100,0 \%\end{array}$ & $\begin{array}{r}33 \\
100,0 \%\end{array}$ & $\begin{array}{r}66 \\
100,0 \%\end{array}$ \\
\hline \multirow{3}{*}{3} & \multirow{3}{*}{ Kebiasaan Menggantung Pakaian } & $\mathrm{Ya}$ & $\begin{array}{r}26 \\
78.8 \% \\
\end{array}$ & $\begin{array}{r}21 \\
63.6 \% \\
\end{array}$ & $\begin{array}{r}47 \\
71,2 \% \\
\end{array}$ \\
\hline & & Tidak & $\begin{array}{r}7 \\
21.2 \% \\
\end{array}$ & $\begin{array}{r}12 \\
36,4 \% \\
\end{array}$ & $\begin{array}{r}19 \\
28.8 \% \\
\end{array}$ \\
\hline & & Jumlah & $\begin{array}{c}33 \\
100.0 \% \\
\end{array}$ & $\begin{array}{r}33 \\
100,0 \%\end{array}$ & $\begin{array}{r}66 \\
100,0 \%\end{array}$ \\
\hline \multirow{3}{*}{4} & \multirow{3}{*}{$\begin{array}{l}\text { Adanya Tempat Penampungan } \\
\text { Alami }\end{array}$} & $\mathrm{Ya}$ & $66,7 \%$ & $\begin{array}{r}16 \\
48,5 \%\end{array}$ & $\begin{array}{r}38 \\
57,7 \%\end{array}$ \\
\hline & & Tidak & $\begin{array}{r}11 \\
33.3 \% \\
\end{array}$ & $\begin{array}{r}17 \\
51.5 \% \\
\end{array}$ & $\begin{array}{r}28 \\
42.5 \% \\
\end{array}$ \\
\hline & & Jumlah & $\begin{array}{r}33 \\
100,0 \%\end{array}$ & $\begin{array}{r}33 \\
100,0 \%\end{array}$ & $\begin{array}{r}66 \\
100.0 \%\end{array}$ \\
\hline \multirow{3}{*}{5} & \multirow{3}{*}{ Kepadatan Hunian } & Tidak Memenuhi & $69,7 \%$ & $\begin{array}{r}20 \\
60.6 \% \\
\end{array}$ & $\begin{array}{r}43 \\
65,2 \% \\
\end{array}$ \\
\hline & & Memenuhi & $\begin{array}{r}10 \\
30.3 \%\end{array}$ & $\begin{array}{r}13 \\
39.4 \%\end{array}$ & $\begin{array}{r}23 \\
34.8 \%\end{array}$ \\
\hline & & Jumlah & $\begin{array}{r}33 \\
100.0 \% \\
\end{array}$ & $\begin{array}{r}33 \\
100.0 \% \\
\end{array}$ & $\begin{array}{r}66 \\
100.0 \% \\
\end{array}$ \\
\hline
\end{tabular}

\section{Kebiasaan mengggunakan Repellent}

Pada kelompok kasus proporsi responden yang tidak menggunakan reppelent (48,5\%) lebih besar dibandingkan dengan yang menggunakan reppelent (51,5\%). Kelompok kontrol proporsi responden yang menggunakan reppelent (72,7\%) lebih besar dibandingkan dengan yang tidak menggunakan reppelent (27,3\%).

Hasil paling tinggi terjadi pada kelompok kontrol yang memiliki kebiasaan menggunakan repellent yaitu $72,7 \%$ sedangkan pada kelompok kasus yang memiliki kebiasaan menggunakan repellent 51,5\% lebih besar persentase responden kasus yang memiliki kebiasaan menggunakan repellent (48,5\%). Hal ini menunjukan penggunaan repellent bagi responden kelompok kasus dan kontrol lebih besar dibandingkan dengan yang tidak memiliki kebiasaan menggunakan repellent.

\section{Adanya Ruang Gelap}

Pada kelompok kasus proporsi adanya ruang gelap (48,5\%) lebih kecil dibandingkan dengan yang tidak ada ruang gelap (51,5\%) begitu juga dengan kelompok kontrol proporsi yang tidak ada ruang gelap (48,5\%) lebih kecil dibandingkan yang ada ruang gelapnya (51,5\%).

Hasil paling tinggi terdapat pada kelompok kontrol yang terdapat ruang gelap yaitu 51,5\% sedangkan pada kelompok kasus yang tedapat ruang gelap 48,5\%. Hal ini menunjukan bahwa ada tidaknya ruang gelap pada kelompok kasus dan kontrol tidak jauh berbeda hanya berbeda satu responden.

\section{Kebiasaan Menggantung Pakaian}

Pada kelompok kasus proporsi kebiasaan menggantung pakaian (78,8\%) lebih besar dibandingkan dengan yang tidak kebiasaan menggantung pakaian ada ruang gelap (21,2\%), kelompok kontrol proporsi yang tidak kebiasaan mengantung pakaian (36,4\%) lebih rendah dibandingkan dengan yang kebiasaan mengantung pakaian (63,6\%).

Hasil paling tinggi pada kelompok kasus yang memiliki kebiasaan menggantung pakaian yaitu dengan persentase 78,8\% dan begitu juga dengan kelompok kontrol hasil tertinggi pada responden yang memliki kebiasaan menggantung pakaian yaitu $63,6 \%$.

\section{Adanya Tempat Penampungan Alami}

kelompok kasus proporsi adanya tempat penampungan alami $(66,7 \%)$ lebih besar dibandingan dengan yang tidak terdapat tempat penampungan alami (33,3\%). Kelompok kontrol yang tidak terdapat tempat penampungan alami (51,5\%) lebih besar 
dibandingkan dengan yang terdapat tempat penampungan alami (48,5\%).

Hasil paling tinggi ditunjukan pada kelompok kasus yang memliki tempat penampungan alami yaitu $66,7 \%$ dan pada kelompok kontrol yang tidak memiliki tempat penampungan alami lebih besar daripada yang memiliki tempat penampungan alami yaitu 51,5\%.

\section{Kepadatan Hunian}

Kelompok kasus proporsi kepadatan hunian yang tidak memenuhi syarat (69,7\%) lebih besar dibandingkan dengan kepadatan hunian yang memenuhi syarat (20,3\%), namun kelompok kontrol proporsi kepadatan hunian yang memenuhi syarat (39,4\%) lebih rendah dibandingkan dengan kepadatan hunian yang tidak memenuhi syarat (60,6\%).

Hasil paling tinggi didapatkan pada kelompok kasus kepadatan hunian tidak memenuhi persyaratan yaitu sebesar 69,7 \% atau 23 rumah responden hal ini dikarenakan wilayah Purwokerto Timur padat penduduk selain itu responden memiliki dua kamar atau lebih namun kamar tidak digunakan untuk tidur sehari-hari namun digunakan untuk tidur.

\begin{tabular}{lccc}
\multicolumn{1}{l}{ Hasil Analisis Bivariate } & & \\
\hline \multicolumn{1}{c}{ Variabel } & P value & OR & Ket \\
\hline $\begin{array}{l}\text { Kebiasaan } \\
\text { menggunakan } \\
\text { reppelent }\end{array}$ & 0,128 & 2,510 & $\begin{array}{l}\text { Tidak ada } \\
\text { hubungan }\end{array}$ \\
\hline $\begin{array}{l}\text { Adanya ruang } \\
\text { gelap }\end{array}$ & 1,000 & 1,129 & $\begin{array}{l}\text { Tidak ada } \\
\text { hubungan }\end{array}$ \\
\hline $\begin{array}{l}\text { Kebiasaan } \\
\text { menggantung } \\
\text { pakaian }\end{array}$ & 0,277 & 2,122 & $\begin{array}{l}\text { Tidak ada } \\
\text { hubungan }\end{array}$ \\
\hline $\begin{array}{l}\text { Adanya tempat } \\
\text { penampungan } \\
\text { alami }\end{array}$ & 0,213 & 2,125 & $\begin{array}{l}\text { Tidak ada } \\
\text { hubungan }\end{array}$ \\
\hline Kepadatan hunian & 0,605 & 1,495 & $\begin{array}{l}\text { Tidak ada } \\
\text { hubungan }\end{array}$ \\
\hline
\end{tabular}

\section{Kebiasaan Menggunakan Repellent}

Hasil uji analisis bivariat menunjukkan p value 0,128 lebih besar dari $\alpha=0,05$ yang artinya tidak ada hubungan antara kebiasaan menggunakan reppelent dengan kejadian DBD di Kecamatan Purwokerto Timur. Hasil perhitungan OR diperoleh angka 2,510 artinya orang yang tidak memiliki kebiasaan menggunakan reppelent akan berpotensi terkena DBD 2,510 lebih besar dibandingkan dengan yang orang memiliki kebiasaan menggunakan reppelent.

Hal ini menunjukan kesadaran masyarakat akan pentingnya mencegah DBD yang sudah menyebar di sekitar lingkungan rumah responden kontrol, sehingga masyarakt disekitar responden banyak melakukan pencegahan yang paling mudah yaitu menggunakan repellent.

Responden yang masih balita ataupun usia dibawah 4 tahun kebanyakan pada saat tidur siang hari orang tuanya memberikan perlindungan terhadap gigitan nyamuk dengan menggunakan kelambu saja tidak menggunakan repellent, namun beberapa penderita yang masih bersekolah lebih banyak melakukan aktivitasnya di sekolah tidak menggunakan repplent dari rumah sehingga penghuni rumah atau responden dapat terkena gigitan nyamuk selama berada di sekolah

Penelitian serupa yang dilakukan Darjito (2008) di Purwokerto Timur bahwa hasil uji Chi Square untuk mengetahui hubungan antara Kebiasaan menggunakan obat nyamuk dengan kejadian DBD di Kecamatan Purwokerto Timur diperoleh $\mathrm{p}$ value sebesar 0,072. Hal ini dapat diartikan bahwa tidak ada hubungan antara kebiasaan menggunakan obat nyamuk dengan kejadian DBD di Kecamatan Purwokerto Timur.

Solusi pada faktor resiko ini adalah meningkatkan rasa waspada kepada gigitan nyamuk yang tidak hanya pada malam hari saja tapi juga pada siang hari, alternatif lainnya bila tidak dapat menggunakan repellent maka gunakan kain kassa pada setiap ventilasi agar nyamuk tidak masuk ke dalam rumah. Pada pagi hari atau sore hari ingin tidur maka sebelum tidur akan lebh baik kamar dispray dengan obat nyamuk untuk mengurangi jumlah nyamuk.

\section{Adanya Ruang Gelap}

Hasil uji analisis bivariat menunjukkan p value 1,000 lebih besar dari $\alpha=0,05$ yang artinya tidak ada hubungan antara adanya ruang gelap dengan kejadian DBD di Kecamatan Purwokerto Timur. Hasil perhitungan OR diperoleh angka 1,129 artinya rumah yang memiliki ruang gelap akan berpotensi terkena DBD 1,129 lebih besar dibandingkan dengan rumah yang tidak memiliki ruang gelap.

Adanya ruang gelap dalam suatu rumah dapat diatasi dengan memberika penerangan buatan dengan menggunakan lampu yang intensitas cahayanya memenuhi syarat yaitu 100 lux, selain itu cara yang lebih efektif yaitu memberikan jendela atau langit langit atap dengan kaca agar sinar matahari dapat masuk ke dalam ruangan yang gelap

\section{Kebiasaan Menggantung Pakaian}

Hasil uji analisis bivariat menunjukkan p value 0,277 lebih besar dari $\alpha=0,05$ yang artinya tidak ada hubungan antara kebiasaan menggunakan menggantung pakaian dengan kejadian DBD di Kecamatan Purwokerto Timur. Hasil perhitungan OR diperoleh angka 2,122 artinya orang yang memiliki kebiasaan menggantung pakaian akan berpotensi terkena DBD 2,122 lebih besar dibandingkan dengan yang orang tidak memiliki kebiasaan menggantung pakaian.

Hasil penelitian ini menunjukan tidak ada hubungan kebiasaan menggantung pakaian dengan kejadian DBD hal ini dikarenakan terdapat variabel faktor lainnya yang lebih berkaitan dan mendukung kebiasaan menggantung pakaian seperti suhu dan kelembapan rumah dan ruang kamar yang digunakan untuk menggantung pakaian sehingga nyamuk 
tertarik untuk beristirahat di pakaian yang menggantung. Selain itu dapat dikarenakan baju yang digantungan tidak semua merupakan baju yang sudah kotor atau terkena keringat dan baju yang sudah digunakan barhari-hari.

Hasil penelitian berbeda didapatkan Darjito dkk (2008) bahwa untuk kelompok kasus jumlah responden yang kebiasaan menggantung pakaian tahun 47 responden (94\%), sedangkan untuk kelompok kontrol sebanyak 44 responden (88\%) dari hasil uji Chi Square untuk mengetahui hubungan antara kebiasaan gantung pakaian dengan kejadian DBD di Kecamatan Purwokerto Timur diperoleh p value sebesar 0,295. Hal ini dapat diartikan bahwa tidak ada hubungan antara kebiasaan menggantung pakaian dengan kejadian DBD di Kecamatan Purwokerto Timur.

Responden maupun masyarakat perlu meningkatkan kepedulian tentang penyakit DBD, dan juga mengurangi kebiasaan sehari-hari yang dapat meimbulkan penyakit salah satu menghilangkan kebiasaan menggantung pakaian hingga berhari-hari terlebih baju yang sudah dipakai lebih dari dua hari sehingga baju baju tersebut menumpuk tidak beraturan. Masyarakat sebaiknya dapat membiasakan diri untuk melipat baju yang sudah dipakai namun tidak begiu kotor sehingga tidak ada pakaian yang bergelantungan. Namun akan lebih baik jika pakaian yang sudah dipakai langsung dimasukan ke dalam wadah yang kering dan tertutup agar tidak menjadi tempat untuk nyamuk beristirahat.

\section{Adanya Tempat Penampungan Alami}

Hasil uji analisis bivariat menunjukkan $\mathrm{p}$ value 0,213 lebih besar dari $\alpha=0,05$ yang artinya tidak ada hubungan antara adanya tempat penampungan alami dengan kejadian DBD di Kecamatan Purwokerto Timur. Hasil perhitungan OR diperoleh angka 2,125 artinya rumah yang memiliki tempat penampungan alami akan berpotensi terkena DBD 2,125 lebih besar dibandingkan dengan rumah yang tidak memiliki tempat penampungan alami.

Adanya tempat penampungan air alami tidak berhubungan dengan kejadian DBD tetapi ada faktor lainnya yang berpengaruh dalam kejadian DBD seperti kolam kolam ikan, tempat minum burung, atau wadah yang digunakan untuk menampung air hujan, dan tempat penampungan lainnya yang berada tempat yang tidak terkena langsung dengan cahaya. Tempat penampungan alami yang banyak ada di responden merupakan tempat penampungan alami seperti kebun-kebun pisang dan potongan pohon bambu yang terkena langsung dengan sinar matahari sehingga nyamuk enggan untuk meletakkan telurnya. Selain itu pada awal tahun 2016 telah terjadi KLB DBD dan Dinas Kesehatan Kabupaten Banyumas genjar melakukan fogging fokus pada saat dilakukan fogging kader desa melakukan PSN disekitar rumah responden DBD sehingga dapat mengurangi kepadatan nyamuk dan jumlah jentik.
Penelitian yang dilakukan Darjito (2008) bahwa Salah satu jenis tempat perkembangbiakkan nyamuk Aedes aegypti yaitu tempat penampungan air alamiah seperti, lubang pohon, lubang batu, pelepah daun, tempurung kelapa, potongan bambu dan Iain-lain. Dari hasil uji Chi Square untuk mengetahui hubungan antara tanaman sekitar rumah dengan kejadian DBD di Kecamatan Purwokerto Timur diperoleh $\mathrm{p}$ value sebesar 0,016. Hal ini dapat diartikan bahwa ada hubungan antara adanya tanaman di sekitar rumah dengan kejadian DBD di Kecamatan Purwokerto Timur.

Solusi atau pemecahan masalah untuk tempat penampungan air alami adalah melalui kegiatan pembrantasan sarang nyamuk (PSN) PSN 3M akan memberikan hasil yang baik apabila dilakukan secara luas dn serentak, terus menerus dan berkesinambungan. PSN sebaiknya dilakukan sekurang-kurangnya seminggu sekali sehingga pertumbuhan nyamuk tidak menjadi dewassa, namun dapat dilakukan sebulan sekali untuk penampungan air alami yang lebih banyak terdapat di kebun kebun

\section{Kepadatan Hunian}

Hasil uji analisis bivariat menunjukkan p value 0,605 lebih besar dari $\alpha=0,05$ yang artinya tidak ada hubungan antara kepadatan hunian dengan kejadian DBD di Kecamatan Purwokerto Timur. Hasil perhitungan OR diperoleh angka 1,495 artinya rumah yang tidak memenuhi syarat kepadatan hunian akan berpotensi terkena DBD 1,495 lebih besar dibandingkan dengan rumah memenuhi syarat kepadatan hunian.

Kepadatan hunian tidak berhubungan dengan kejadian DBD dikarenakan Jika dalam satu rumah tangga ada yang menderita DBD maka pada kepadatan hunian tinggi diasumsikan akan lebih besar peluang untuk terjadinya penularan penyakit DBD diantara anggota rumah tangga tersebut lebih tinggi dibandingkan dengan rumah tangga dengan kepadatan hunian yang rendah. Namun penularan DBD tidak hanya terjadi di rumah saja namun juga dapat tertular DBD di sekolah ataupun tempat umum lainnya. Selain itu pada kepadatan hunian yang tidak sesuai pada kelompok kontrol sebanyak 20 responden (60,6\%) lebih tinggi dibandingkan dengan kepadatan hunian yang sesuai yaitu 13 responden $(39,4 \%)$.

Faktor kepadatan hunian tidak tidak berhubungan dengan kejadian DBD dikarenakan responden penghuni rumah melakukan banyak aktivitas di dalam rumah walaupun rumah padat penghuni, selain itu tidak selalu penghuni rumah tidur dalam kamar yang sama terus menerus pada pagi hari dalam arti penghuni rumah sering berpergian dan melakukan aktivitas di luar rumah seperti bekerja dan sekolah, responden hanya menempati kamar tidur pada malam hari saja.

Penelitian yang dilakukan oleh M. Hasyimi dkk (2007) menunjukan hasil yang sama, analisis hubungan antara kepadatan hunian dan kejadian DBD 
dengan uji chi square didapatkan nilai $\mathrm{p}=0,752$, berarti pada $\mathrm{a}=5 \%$ tidak ada perbedaan yang bermakna antara dua variable tersebut. Dapat dikatakan bahwa hubungan antara kepadatan hunian tidak ada perbedaan yang bermakna bila dikaitkan dengan kejadian kasus DBD. Dengan confident interval (tingkat kepercayaan) $95 \%$, responden dengan kepadatan hunian $<8 \mathrm{~m}^{2}$ mempunyai risiko terjangkit penyakit DBD hampir sama dengan responden dengan kepadatan hunian $>8 \mathrm{~m}^{2}$ (OR 1,05 dan 1).

Obeservasi yang ditemukan di lapangan dalam satu rumah terdapat kamar lebih dari satu namun kamar tersebut tidak digunakan untuk tidur melainkan digunakan untuk barang-barang, gudang, bahkan tempat untuk pakaian yang tidak dimasukan ke dalam lemari sehingga mereka lebih memilih tidur bersama dalam satu kamar. Hal ini sebaiknya menggunakan kembali kamar yang kosong untuk beristirahat dan tidur.

\section{Hasil Analisis Multivariat}

\begin{tabular}{llccc}
\hline No & Variabel Independent & P & B & $\begin{array}{c}\text { CI } \\
(\mathbf{9 5 \% )}\end{array}$ \\
\hline 1 & Kebiasaan & 0,079 & 2,510 & $0,899-$ \\
& mengunakan Reppelent & & & 7,003 \\
\hline
\end{tabular}

Hasil akhir analisis regresi logistik dengan metode Backward: LR dari semua variable yang sudah masukan secara bersama-sama yaitu kebiasaan menggunaan repellent, adanya ruang gelap, kebiasaan menggantung pakaian, adanya tempat penampungan alami, dan kepadatan hunian. Variabel yang paling signifikan diantara variabel yang diuji dan berhubungan dengan kejadian DBD adalah kebiasaan menggunakan repellent dengan nilai $\mathrm{p}=0,079$ dan $\mathrm{OR}=2,510$. Artinya bahwa orang yang tidak mempunyai kebiasaan menggunakan repellent berisiko terkena DBD 2,510 kali lebih tinggi dibandingkan dengan orang yang mempunyai kebiasaan menggunakan repellent.

Setelah dilakukan uji regresi logistik, diketahui bahwa hubungan variabel dengan kejadian DBD yang paling berpengaruh atau signifikan adalah variabel kebiasaan menggunakan reppelent dengan nilai ( $\mathrm{p}=$ 0,079 ) dimana penelitian ini menggunakan derajat kepercayaan 95\%, dimana hubungan antar variabel dikatakan bermakna jika $\mathrm{p}<0,05$ dan tidak bermakna jika $\mathrm{p}>0,05$. Meskipun kebiasaan menggunakan reppelent tidak bermakna namun kebiasaan menggunakan repplent merupakan faktor yang paling signifikan diantara empat variabel lainnya yang diuji. Berikut urutan faktor yang berubungan dengan kejadin DBD dimulai dari nilai p terendah atau faktor yang paling signifikan; 1. Kebiasaan menggunakan reppelent $(p=0,079)$, 2. Kebiasaan menggantung pakaian $(p=0,139), 3$. Kepadatan hunian $(p=0,271)$, 4. Tempat penampungan alami $(p=0,466), 5$. Adanya ruang gelap $(\mathrm{p}=0,898)$.

Tingkat kesadaran dan pengetahuan masyarakat tentang tindakkan pencegahan gigitan nyamuk itu kebanyakan hanya pada malam hari saja, namun mereka tidak menyadari bahwa aktivitas nyamuk Aedes aegypti pada pagi hari (pukul 09.00-10.00) dan sore hari (pukul 16-17.00).

Responden yang masih bersekolah akan banyak menghabiskan waktunya di sekolah dari pagi hingga sore sehingga masyarakat atau responden melupakan untuk memakai reppelent. Berbeda dengan responden yang masih balita ataupun usia dibawah 4 tahun kebanyakan pada saat tidur siang hari orang tuanya memberikan perlindungan terhadap gigitan nyamuk dengan kelambu atau hanya dengan selimut saja.

Sebagian penderita yang didapatkan memiliki kebiasaan menggunakan obat anti nyamuk pada pagi hari dan sore hari tetapi tetap menderita DBD ini dikarenakan faktor lainnya seperti adanya jentik dalam konteiner air, kemudian pemasangan kawat kassa pada ventilasi,dan fakto-faktor lainnya yang lebih signifikan.

\section{IV.SIMPULAN DAN SARAN}

\section{Simpulan}

a. Variabel yang berisiko dengan kejadian DBD dari variabel yang diuji adalah sebagai berikut:

1. Kebiasaan menggunakan reppelent dengan persentase tertinggi $72,7 \%$ yaitu pada kelompok kontrol yang memiliki kebiasaan menggunakan reppelent, dengan nilai signifikan 0,079.

2. Adanya ruang gelap dengan persentase tertinggi $51,5 \%$ yaitu pada kelompok kontrol yang terdapat ruang gelap dan pada kelompok kasus yang tidak terdapat ruang gelap, dengan nilai signifikan 0,898.

3. Kebiasaan menggantung pakaian dengan persentase tertinggi $78,8 \%$ yaitu pada kelompok kasus yang memiliki kebiasaan menggantung pakaian, dengan nilai signifikan 0,139 .

4. Adanya tempat penampungan alami dengan persentase tertinggi $66,7 \%$ yaitu pada kelompok kasus yang terdapat tempat penampungan alami, dengan nilai signifikan 0,466 .

5. Kepadatan hunian dengan persentase tertinggi 69,7\% yaitu pada kelompok kasus yang kepadatan huniannya tidak memenuhi syarat, dengan nilai sigifikan 0,271.

b. Tidak ada hubungan antara kebiasaan menggunakan repellent dengan kejadian DBD di Kecamatan Purwokerto Timur Tahun 2016, dengan nilai $\mathrm{p}$ value $=0,128 ; \mathrm{OR}=2,510$

c. Tidak ada hubungan antara adanya ruang gelap dengan kejadian DBD di Kecamatan Purwokerto Timur Tahun 2016, dengan nilai p value $=1,000$; $\mathrm{OR}=1,129$

d. Tidak ada hubungan antara kebiasaan menggantung pakaian dengan kejadian DBD di 
Kecamatan Purwokerto Timur Tahun 2016, dengan nilai $\mathrm{p}$ value $=0,277 ; \mathrm{OR}=2,122$

e. Tidak ada hubungan antara adanya tempat penampungan alami dengan kejadian DBD di Kecamatan Purwokerto Timur Tahun 2016, dengan nilai $\mathrm{p}$ value 0,213 ; $\mathrm{OR}=2,125$;

f. Tidak ada hubungan antara kepadatan hunian dengan kejadian DBD di Kecamatan Purwokerto Timur Tahun 2016, dengan nilai $\mathrm{p}$ value $=0,605$ OR $=1,495$

g. Hasil akhir analisis regresi logistic, variabel yang paling signifikan diantara variabel yang diuji adalah kebiasaan menggunakan repellent dengan nilai $\mathrm{p}$ value $=0,079$ dan $\mathrm{OR}=2,510$.

\section{Saran}

a. Kepada pemerintahan khususnya Dinas Kesehatan Kabupaten Banyumas diharapkan dapat mendukung dan begitu juga dengan masyarakat untuk berkerja sama dalam melaksanakan pemberantasan sarang nyamuk dengan melakukan $3 \mathrm{M}$ plus yaitu menguras, menutup, dan mengubur dan membubuhkan abate pada tempat penampungan air yang jarang dikuras secara serentak dan berkesinambungan, dibantu oleh keder-kader dan perangkat desa untuk selalu melakukan dan mengawasi PSN dan 3M.

b. Bagi institusi dan peneliti untuk belajar dan memperdalam tentang penyakit DBD, melakukan banyak penelitian dengan berkembangnya kemampuan nyamuk Aedes aegypti beradaptasi dengan lingkungan, selain itu mempelajari lagi perkembangan dari kemampuan virus dengue yang bisa terdapat di telur nyamuk. Peneliti dapat mengembangkan atau melanjutkan skripsi ini dengan menambahkan variabel bebasnya

c. Bagi masyarakat untuk selalu mewaspadai gigitan nyamuk dan meninggalkan segala kebiasaan buruk yang dapat mengundang nyamuk ke dalam rumah, dan kesadaran diri untuk selalu hidup bersih padan peduli pada lingkungan sekitar rumah.

\section{DAFTARPUSTAKA}

Achmad Umar Fahmi, dkk, Buletin Jendela Epidemologi: Demam Berdarah Dengue, ISSN-2087-1546 Volume, 2 Agustus 2010

Akhsin Zukoni. 2010. Parasitologi. Yogyakarta : Anggota IKAPI. Badan Pusat Kabupaten Banyumas. 2015, Kecamatan Purwokerto Timur dalam Angka 2015. Badan Pusat Kabupaten Banyumas. Purwokerto

Cecep Dani Sucipto. 2011. Vektor Penyakit Tropis. Yogyakarta: Gosyen Publishing

Dardjito Endo, dkk. 2008. Beberapa Faktor yang Berpengaruh Terhadap Kejadian Penyakit
DBD Di Kabupaten Banyumas. Media Litbang Kesehatan Vol XVII No.3

Genis Ginanjar. 2007. Apa yang Dokter Anda Tidak Katakan Tentang Demam Berdarah. Edisi 1. Bandung : Bintang Pustaka

Margatan, Arcole. 1996. Mewaspadai Demam Berdarah dan Berbagai Macam Demam Lainnya. Solo: Toko Buku Agency.

Mustazahid Agfadi Wirayoga, 2013, Hubungan Kejadian Demam Berdarah Dengue Dengan Iklim di Kota Semarang Tahun 2011 - 2016, Semarang : Universitas Negeri Semarang Jurusan Kesehatan Masyarakat

PBB Indonesia. 2015 (diakses pada tanggal 11 Januari 2016, 17:37 WIB)

Santjaka Aris, 2011. Statistic untuk penelitian kesehatan. Yogyakarta: Nuba Medika

Santoso Fitri. 2010. Analisis Faktor Yang Berhubungan Dengan Kejadian Chikungunya Di Wilayah Kerja Puskesmas Gunungpati Kota Semarang. Semarng: Universitas Negeri Semarang

Sembel, T.D. 2009. Entomologi Kedokteran. Jogjakarta : Andi

Soegeng Soegijanto . 2006 . Demam Berdarah Dengue Edisi 2 . Surabaya: Airlangga University Press

Suroso Thomas, 1986. Demam Berdarah Dengue Epidemologi dan Pemberantasan Di Indonesia. Jakarta : DIT .JEN. PP \& PL

Teguh Widiyanto. 2007. Kajian Manajemen Lingkungan Terhadap Kejadian Demam Berdarah Dengue (DBD) di Kota Purwokerto Jawa - Tengah, Universitas Dipenogoro Semarang

Tri Cahyono. 2014, Pedoman Penulisan dan Karya Tulis Ilmiah/ Skripsi Edisi Revisi Ketiga, Purwokerto : Kemenkes RI Politeknik Kesehatan Semarang Jurusan Kesehatan Lingkungan Purwokerto

Widia Eka Wati, 2009. Beberapa Faktor Yang Berhubungan Dengan Kejadian Demam Berdarah Dengue (Dbd) Di Kelurahan Ploso Kecamatan Pacitan, Universitas Muhammadiyah Surakarta 
Widiyono, 2008, Penyakit Tropis Epidemiologi, Penularan, Pencegahan \& Pemberantasannya, Jakarta : Erlangga

Widodo, 2012, Faktor-Faktor yang Berhubungan Dengan Kejadian DBD DI kota Mataram Provinis NTB, Depok : Fakultas Kesehatan Masyarakat Universitas Indonesia

Wisfer, dkk. 2014. Hubungan Jumlah Penghuni, Tempat Penampungan Air Keluarga dengan
Keeradaan Larva Aedes aegypty di Wilayah Endemis DBD Kota Makasar, Fakultas Kesehatan Masyarakat Unhas

World Health Organization (WHO), 1998, Diagnosis, Pengobatan, Pencegahan, dan Pengendalian, Jakarta : Buku Kedokteran EGC 